\section{Advantages of fixed stored materials for immunoelectron microscopy, with special reference to the study of malignant lymphomas}

\author{
H AKATSUKA, K KITO, M SHAMOTO,* T S.UCHI \\ Department of Pathology and Clinical Laboratories, \\ Aichi Cancer Center Hospital, 81-1159, Kanokoden \\ Tashiro-cho Chikusa-ku, Nagoya 464, Japan, and the \\ *Department of Pathology, Fujita-Gakuen, \\ University School of Medicine, Toyoake, Aichi, \\ Japan
}

Recent developments in the production of monoclonal antibodies have helped considerably in understanding the human immune system and its abnormalities. The distinction of $T$ cell subsets is important not only in studies of the functional characteristics of lymphocytes but also in the investigation of the neoplastic processes of lymphocytes. $^{1-4}$ Immunoelectron microscopic methods allow identification of lymphocytes by means of their ultrastructural characteristics. ${ }^{56}$ It is difficult, however, to achieve satisfactory preservation of morphology at the electron microscopic level while preserving antigenicity, and usually all procedures must be carried out successively and without delay after the specimens are taken. We report here a method by which both antigens and ultrastructural morphology can be preserved for at least one year after fixation.

\section{Material and methods}

Ten lymph node biopsies each from $T$ and $B$ cell lymphomas diagnosed by clinical, histological, and immunological examination and five non-neoplastic lymph nodes were used for this study.

\section{FIXATION, EMBEDDING, AND STORAGE}

Specimens were cut into slices less than $1 \mathrm{~mm}$ thick. They were fixed in a periodate-lysineparaformaldehyde ${ }^{7}$ for $4-6 \mathrm{~h}$ at $4^{\circ} \mathrm{C}$ with continuous agitation. Then they were washed in two to three changes of cold phosphate buffered saline (PBS). The specimens were agitated gently at $4^{\circ} \mathrm{C}$ in PBS containing $10 \%$ sucrose overnight, $15 \%$ sucrose for $8 \mathrm{~h}, 20 \%$ sucrose again overnight, and $20 \%$ sucrose with $10 \%$ glycerin for $5 \mathrm{~h}$. The tissues were then completely embedded in OCT compound (Miles Laboratories Inc), quickly snap frozen by liquid

Accepted for publication 14 March 1984 nitrogen, and stored at $-80^{\circ} \mathrm{C}$ until required. On the basis of specimens examined so far, we have been able to preserve tissue satisfactorily at $-80^{\circ} \mathrm{C}$ for up to one year, but it may be possible to preserve specimens for several years. When specimens are to be sectioned, they should be cut as soon as possible after removal from the deep freeze.

\section{SECTION CUTTING AND STAINING}

Sections of $10 \mu \mathrm{m}$ thickness were cut in a cryostat and mounted on albumin coated slides. The sections on the slides were air dried for at least $1 \mathrm{~h}$ and then dried in a desiccator at $4^{\circ} \mathrm{C}$ overnight to ensure adhesion. They could be preserved in the desiccator at $4^{\circ} \mathrm{C}$ for three months. Before the sections were used, the desiccator in which they were kept was brought to room temperature in order to prevent condensation on the slides.

After washing in two to three changes of cold PBS containing $10 \%$ sucrose, the sections were allowed to react with appropriate antibodies-namely, OKT-3, 4 (Ortho Pharmaceuticals Ltd), Leu 3A and Leu 4 (Becton Dickinson Facs Systems), or both; OKT-8, OKIa (Ortho Pharm Ltd); and B1 (Coulter Electronics Inc). For negative control sections normal mouse serum was substituted for each primary antibody.

A three step immunoperoxidase technique was applied, using peroxidase-antiperoxidase (PAP) complex (mouse) specifically made for this purpose in our laboratory: first, the sections were allowed to react with the above optimally diluted antibodies in the wet chamber at room temperature for $2 \mathrm{~h}$. Then they were washed in two to three changes of cold PBS containing $10 \%$ sucrose for $1 \mathrm{~h}$ at $4^{\circ} \mathrm{C}$ and incubated with biotinylated horse antimouse IgG (Vector Laboratories Inc) for $2 \mathrm{~h}$ at room temperature. They were again washed overnight in cold PBS containing $10 \%$ sucrose at $4^{\circ} \mathrm{C}$ and then incubated with both avidin-biotinylated peroxidase complex (Vector Laboratories Inc) and PAP complex (mouse) $^{589}$ for $4 \mathrm{~h}$ at room temperature in the wet chamber.

After incubation they were washed in cold PBS containing $10 \%$ sucrose for $1 \mathrm{~h}$, fixed in $2 \%$ glutaraldehyde for $10 \mathrm{~min}$ at room temperature, and washed again in two to three changes of cold PBS for $30 \mathrm{~min}$. After this they were incubated first for 30 min in Karnovsky's solution without hydrogen peroxide and then in complete Karnovsky's solution for $10 \mathrm{~min}$ at room temperature, before washing in two to three changes of cold PBS for $15 \mathrm{~min}$. The slides were then postfixed in $2 \% \mathrm{OsO}_{4}$ for $1-2 \mathrm{~h}$ at room temperature.

After dehydration in graded series of alcohol at 5-10 min intervals, the sections were embedded in 

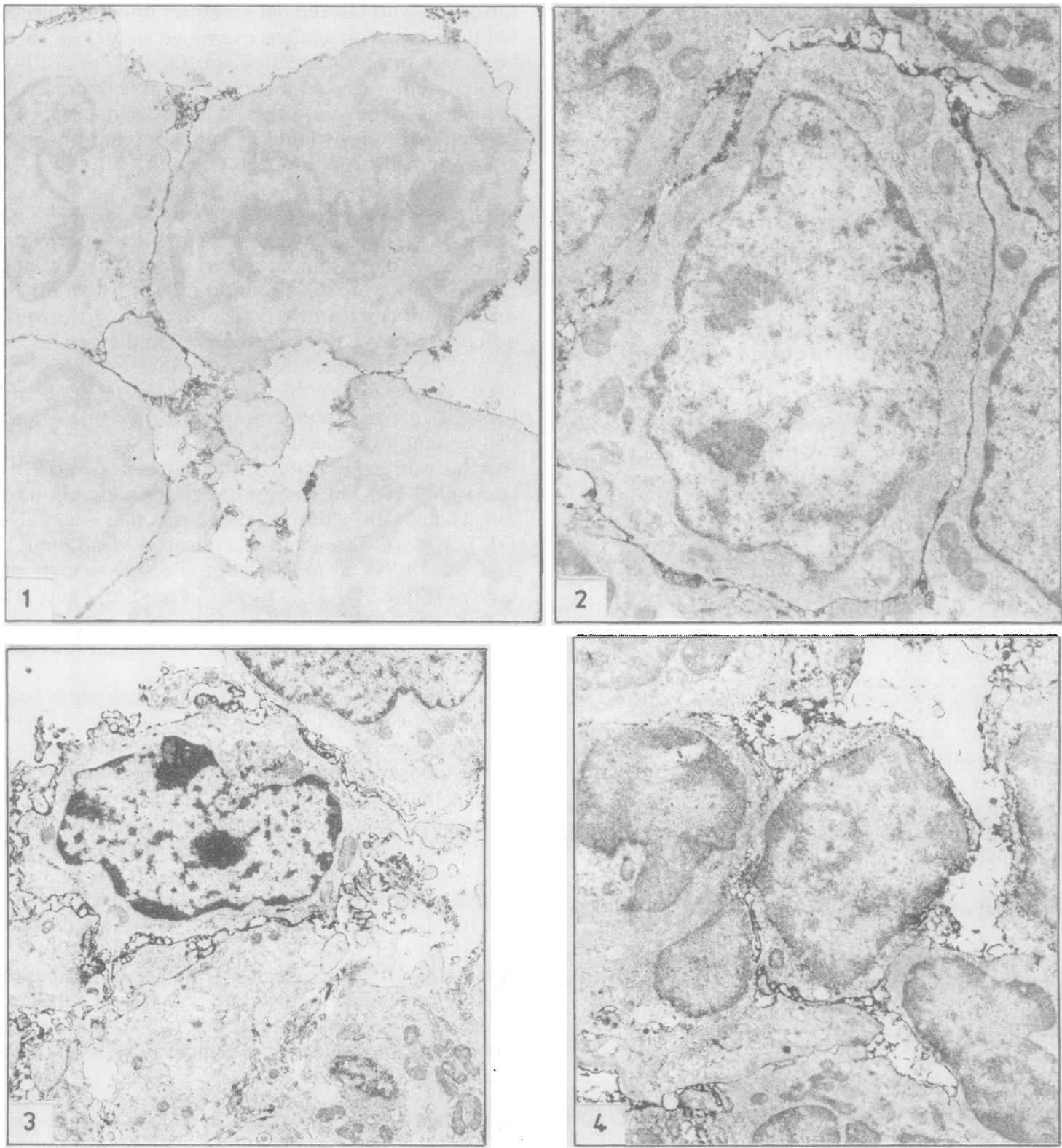

Fig. 1 A case of adult $T$ cell leukaemia, OKT-3+4+ $8^{-} . O K T-4$ positive cells are seen. Stored for 12 months. Unstained. $\times 4400$.

Fig. 2 A case of $T$ cell lymphoma, OKT $-3^{+} 4^{-} 8^{+}$. OKT-8 positive cells are seen. Stored for six months. Stained. $\times 8100$.

Fig. 3 Case of B cell lymphoma. B-1 positive cells are found. Stored for six months. Stained. $\times 4400$.

Fig. 4 Case of B cell lymphoma. Ia positive cells are found. Stored for six months. Stained. $\times 5200$. 
epoxy resin, quickly inverting a resin filled gelatin capsule on the section surface. During the entire procedure described the section remained attached to the slide. Following polymerisation of the resin, detachment of the capsule from the glass slide was facilitated by heating it over a Bunsen flame. Ultrathin sections were cut with a diamond knife on an LKB Ultratome and were examined either unstained or stained with uranyl acetate and lead under a Jeolco $100 \mathrm{CX}$ electron microscope.

\section{Results and discussion}

The cases studied included $\mathrm{T}$ cell malignancies which might have been related in their origin to phenotypically and functionally distinct $T$ cell subsets - in other words, OKT $-3^{+} 4^{+} 8^{-}$and OKT $-3^{+} 4^{-} 8^{+}$lymphomas, which could be commonly associated with helper/inducer and supressor/ cytotoxic functions. B cell malignancies were also studied.

The specimen shown in Fig. 1 was obtained from a case of adult $T$ cell leukaemia. The plasma membrane of lymphoid cells with convoluted and indented nuclei was positive with OKT-4 antibody but negative with OKT- 8 antibody. The cells of the adult $\mathrm{T}$ cell leukaemia showed characteristic features previously described..$^{10}$ The plasma membrane of neoplastic lymphoid cells was positive with OKT -8 antibody in a case of OKT- 8 positive T cell lymphoma (Fig. 2). On the other hand, the plasma membrane of B cell lymphoma was positive with B1 antibody (Fig. 3). Several Ia positive cells were also seen in a B cell lymphoma (Fig. 4). The method was useful not only for ultrastructural comparisons of neoplastic $\mathrm{T}$ and $\mathrm{B}$ lymphoid cells but also for the better characterisation of the $T$ cell subsets.

Satisfactory preservation of ultrastructural morphology cannot always be obtained in immunoelectron microscopic studies by conventional methods. Moreover, it is not possible, by conventional methods, to repeat the reaction procedures when a first trial has failed. The new method enables us to repeat the reaction or apply new antibodies as they become available; while sections are available from stock. The residues of specimens after cutting can also be stored again by rapid freezing in OCT compound as described.

The washing time in this method may be rather long. Since more than $5 \mathrm{~h}$ is given to each step, to permit the penetration of liquid into the entire specimen, some minor adjustment of time is possible. The procedures after freezing can be per- formed at any time if specimens are fixed according to our methods. We have usually carried out procedures on several cases simultaneously. Some investigators ${ }^{11} 12$ also store the specimens for light microscopic studies at $-70^{\circ} \mathrm{C}$ until use. These stored specimens cannot be used for electron microscopic studies, however, because ultrastructural morphology may be poor. The specimens illustrated here had been stored in the freezer at $-80^{\circ} \mathrm{C}$ for $6-12$ months.

\section{References}

' Bernard A, Boumsell L, Reinherz EL, et al. Cell surface characterization of malignant $T$ cells from lymphoblastic lymphoma using monoclonal antibodies: Evidence for phenotypic differences between malignant $T$ cells from patients with acute lymphoblastic leukemia and lymphoblastic lymphoma. Blood 1981;57:1105-10.

${ }^{2}$ Haynes BF, Hensley LL, Jegasothy BV. Phenotypic characterization of skin-infiltrating $T$ cells in cutaneous $T$-cell lymphoma: Comparison with benign cutaneous $\mathrm{T}$-cell infiltrates. Blood 1982;60:463-73.

${ }^{3}$ Knowles II DM, Halper JP. Human T-cell malignancies. Correlative clinical histopathologic, immunologic, and cytochemical analysis of 23 cases. Am J Pathol 1982;106:187-203.

4 Kung PC, Berger CL, Coldstein G, LoGerfo P, Edelson RL. Cutaneous $\mathrm{T}$ cell lymphoma: Characterization by monoclonal antibodies. Blood 1981;57:261-6.

${ }^{5}$ Cerf-Bensussan N, Schneeberger EE, Bhan AK. Immunohistologic and immunoelectron microscopic characterization of the mucosal lymphocytes of human small intestine by the use of monoclonal antibodies. J Immunol 1983;130:2615-22.

- Murphy GF, Bhan AK, Sato S, Mihm MC, Harrist TJ. A new immunologic marker for human Langerhans cells. $N$ Engl $J$ Med 1981;304:791-2.

${ }^{7}$ McLean IW, Nakane PK. Periodate-lysine-paraformaldehyde fixative: a new fixative for immunoelectron microscopy. $J$ Histochem Cytochem 1974;22:1077-83.

${ }^{8}$ Guesdon JL, Ternynck T, Avrameas S. The use of avidin-biotin interaction in immunoenzymatic techniques. $J$ Histochem Cytochem 1979;27:1131-9.

${ }^{9}$ Hsu SM, Raine L, Fanger $H$. Use of avidin-biotin-peroxidase complex (ABC) in immunoperoxidase techniques: A comparison between ABC and unlabeled antibody (PAP) procedures. J Histochem Cytochem 1981;29:557-80.

10 Shamato M, Murakami S, Zenke T. Adult T-cell leukemia in Japan: An ultrastructural study. Cancer 1981;47:1804-11.

"Bhan AK, Nadler LM, Stashenko P, McCluskey RT, Schlossman SF. Stages of B cell differentiation in human lymphoid tissue. $J$ Exp Med 1981;154:737-49.

12 McMillan EM, Wasik R, Everett MA. Identification of T-lymphocytes and T-subsets in human tonsil using monoclonal antibodies and the immunoperoxidase technic. Am J Clin Pathol 1981;76:737-44.

Requests for reprints to: Hiromichi Akatsuka MT, Department of Pathology and Clinical Laboratories, Aichi Cancer Center Hospital 81-1159, Kanokoden Tashiro-cho Chikusa-ku, Nagoya 464, Japan. 